\title{
Clostridium difficile: A healthcare-associated infection of unknown significance in adults in sub-Saharan Africa
}

\author{
Alexander J. Keeley ${ }^{1}$, Nicholas J. Beeching ${ }^{1,2,3}$, Katharine E. Stott ${ }^{1}$, Paul Roberts ${ }^{4}$, Alastair Watson ${ }^{5}$, \\ Michael J. Beadsworth ${ }^{1,2}$
}

1. Tropical and Infectious Disease Unit, Royal Liverpool University Hospital, Liverpool, United Kingdom

2. Department of Clinical Sciences, Liverpool School of Tropical Medicine, Liverpool, United Kingdom

3. Health Protection Research Unit in Gastrointestinal Infections, National Institute for Health Research, University of Liverpool, Liverpool, United

Kingdom

4. Department of Infection and Immunity, Royal Liverpool University Hospital, Liverpool, United Kingdom

5. Norwich Medical School, University of East Anglia, Norwich Research Park, Norwich, United Kingdom

Correspondence to: Michael J. Beadsworth (Mike.Beadsworth@rlbuht.nhs.uk)

\section{Background}

Abstract

Clostridium diffcile infection (CDI) causes a high burden of disease in high-resource healthcare systems, with significant morbidity, mortality, and financial implications. CDI is a healthcare-associated infection for which the primary risk factor is antibiotic usage, and it is the leading cause of bacterial diarrhoea in HIV-infected patients in the United States. Little is known about the disease burden of CDI in sub-Saharan Africa, where HIV and healthcare-associated infections have higher prevalences, and antibiotic usage is less restricted. This article reviews published literature on CDI in sub-Saharan Africa, highlighting areas for future research.

Methods

English language publications since 1995 were identified from online databases (PubMed, Medline, Google Scholar, and SCOPUS), using combinations of keywords "C. difficile", "Africa", and "HIV".

Results

Ten relevant studies were identified. There was considerable variation in methodology to assess for carriage of toxigenic $C$. difficile and its associations. Eight studies reported carriage of toxigenic $C$. difficile. Three (of three) studies found an association with antibiotic usage. One (of four) studies showed an association with HIV infection. One study showed no association with degree of immunosuppression in HIV. Two (of three) studies showed an association between carriage of toxigenic C. difficile and diarrhoeal illness.

Conclusions

While the carriage of toxigenic $C$. difficile is well described in sub-Saharan Africa, the impact of CDI in the region remains poorly understood and warrants further research.

\section{Introduction}

Clostridium difficile, an anaerobic gram-positive spore-forming bacterium, was first described following isolation from neonatal intestinal tissue in 1935, and was initially presumed to be a commensal organism. ${ }^{1}$ C. difficile was later recognised to cause pseudomembranous colitis via toxin production, and it has since emerged as a major enteric pathogen., ${ }^{2,3}$ Its clinical significance ranges from asymptomatic carriage to life-threatening colitis, with significant associated morbidity and mortality. $C$. difficile colonises the large bowel following ingestion of spores, which are heat and acid resistant. ${ }^{4}$ The spores can be found in most healthcare settings and in the general environment. ${ }^{5,6}$ Gut damage in susceptible individuals results from production of the enterotoxin TcdA, which damages the intestinal epithelium, and the cytotoxin TcdB, which has broader cellular tropism. ${ }^{7}$ The emergence of the 027/BI/NAP1 strain, with dramatically increased cytotoxin production, is responsible for the observed increased prevalence and virulence of $C$. difficile in recent years. ${ }^{8-10}$ This strain emerged in North America and Western Europe and rapidly disseminated worldwide. ${ }^{11}$

The primary risk factor for $C$. difficile infection (CDI) is antibiotic usage. CDI is known to be the cause of up to $25 \%$ of antibiotic-associated diarrhoea. ${ }^{12}$ CDI was originally described following clindamycin use but is now known to complicate the use of many broad-spectrum antibiotics, particularly cephalosporins, co-amoxiclav, and fluoroquinolones. ${ }^{3,13}$ Following antibiotic usage, there is an imbalance in the normal gut flora and $C$. difficile overgrowth can lead to pseudomembranous colitis in susceptible individuals. ${ }^{14}$ Other described risk factors for CDI include hospital admission, exposure to an infected carrier, advanced age, and immunosupression. ${ }^{15}$ The importance of proton pump inhibitors and of other interventions that reduce the gastric acid barrier in increasing susceptibility to CDI remains controversial. ${ }^{16,17}$ There is a described relationship between CDI and HIV, wherein $C$. difficile is known to be the leading cause of bacterial diarrhoea among HIVinfected populations in the United States, but it is not clear how much this reflects increased exposure to healthcare compared to HIV-negative individuals. ${ }^{18,19}$ Only two studies show a convincing association between CDI and low CD4 count, and interpretation of these results is difficult given the high rates of $C$. difficile colonisation in HIV-infected populations. ${ }^{19-22}$

While CDI has been extensively researched in well-resourced health systems, there are few published studies about CDI in sub-Saharan Africa. Healthcare-associated infections cause a greater disease burden in healthcare systems with fewer resources. ${ }^{23}$ Furthermore, in sub-Saharan Africa there is widespread availability of broad-spectrum antibiotics and fewer controls on their usage. ${ }^{24}$ Finally, HIV is far more prevalent in sub-Saharan Africa than in the United States or Europe. It is, therefore, possible that CDI plays an important role in diarrhoeal illness in sub-Saharan Africa, yet there are few published data on the subject. Published infection rates vary greatly, with some authors describing $0 \%$ toxigenic $C$. difficile detection in Kenya and Zambia, while the highest 
published rate is from Nigeria at $43 \% .25-27$ The nature of the relationship between HIV and CDI in sub-Saharan Africa remains poorly understood.

The aims of this review are to describe current published literature regarding CDI in adults in sub-Saharan Africa, and to highlight areas warranting further research.

\section{Methods}

In order to identify English-language publications since 1995 assessing CDI in adults in sub-Saharan Africa, online databases (PubMed, Medline, Google Scholar, and SCOPUS) were searched, using combinations of keywords "C. difficile", "Africa", and "HIV". All relevant papers, in English, from 1995 onwards were included in the review, and their bibliographies were reviewed for relevant papers. Papers that looked for $C$. difficile in children were excluded. Papers looking at adults and children were only included if it was possible to distinguish between the two populations. In total ten relevant studies were found. Data were extracted from relevant papers using a standardised pro forma.

\section{Results}

Ten studies looked for toxigenic C. difficile carriage in sub-Saharan Africa. Of these, eight described toxigenic C. difficile carriage. Two studies from Kenya (1998) and Zambia $(2000)^{6}$ did not find carriage of toxigenic C. difficile. ${ }^{25,26}$ There was considerable variation in laboratory methodology used to identify $C$. difficile and in the populations studied. Furthermore, there was wide variation in the methodology used to assess the association of CDI with recent antibiotic usage, HIV, diarrhoea, and degree of immunosuppression. Table 1 summarises current published studies of CDI in adult populations in different countries in sub-Saharan Africa.

\section{Discussion}

The majority of published studies, and all studies after the year 2000, describe carriage of toxigenic $C$. difficile in adult populations in sub-Saharan Africa. In three studies, which assessed recent antibiotic usage, there was a significant association between antibiotic usage and CDI; however, no studies were designed to implicate individual antibiotics, nor to describe the nature of antibiotic usage. ${ }^{29,30,34}$ These findings are consistent with the well-described risk factor of antibiotic usage in high-resourced healthcare systems. In three of four studies that assessed association with HIV status, no association was found. The only study claiming an association between HIV status and CDI in adults was from Nigeria. However, it compared toxigenic C. difficile carriage in an entirely HIV-positive sample from an urban teaching hospital, with a control population from a different geographical region, wherein HIV status was presumed to be negative if unknown. ${ }^{27} \mathrm{~A}$ study of adults and children in Tanzania found a significant difference in toxigenic $C$. difficile carriage between HIV-positive and HIV-negative individuals. It was not possible, however, to distinguish between adults and children in this analysis, and the number of adults in the study was low. ${ }^{34}$ The lack of association between CDI and HIV status in adults differed from observations in high-resource healthcare systems in the United States and Europe. ${ }^{18,20,21}$ The only study to assess the association between degree of immunosuppression in HIV and CDI was from Malawi. ${ }^{31}$ This study showed no significant association between carriage of toxigenic $C$. difficile and severe immunosuppression (CD4+ cell counts less than 50 $\times 10^{6} / \mathrm{L}$ ), although numbers in this group were small. This http://dx.doi.org/10.4314/mmj.v28i2.8 warrants assessment in a larger study population.

A further area of uncertainty is the role that $C$. difficile plays in diarrhoeal illness, as opposed to asymptomatic infection and incidental detection, in populations studied in sub-Saharan Africa. Table 1 shows that a wide variety of laboratory methods have been used to detect $C$. difficile in the different studies, with different sensitivities and specificities. Methods that use cytotoxicity or immunogenic assays to $\operatorname{detect} C$. difficile toxin reliably detect invasive CDI but sensitivity is variable and dependant on laboratory technique, while methods based solely on polymerase-chain-reaction (PCR) assays probably result in overdiagnosis. ${ }^{35-38}$ Only one study used the two-step diagnostic algorithms currently recommended in many countries, using assays for faecal $C$. difficile glutamate dehydrogenase (GDH) as a screening test for presence of infection, followed by confirmatory PCR for cytotoxin genes to diagnose invasive disease potential. ${ }^{35}$ The majority of studies assessed $C$. difficile in patients with diarrhoea and did not compare these to non-diarrhoeal controls. However, the most robust study of CDI in sub-Saharan Africa showed a clear association between detection of toxigenic $C$. difficile and symptomatic diarrhoeal illness in South Africa. ${ }^{29}$ Another study of adults and children in Tanzania detected toxigenic C. difficile in 9 of 141 subjects with diarrhoea, compared to none in the stools of 109 symptom-free controls. ${ }^{34}$ While asymptomatic carriage has been well documented and has demonstrated to contribute to ongoing transmission of $C$. difficile in well-resourced healthcare systems, its significance in sub-Saharan Africa is uncharacterised. ${ }^{21,22,39,40}$

Only one study on CDI in South Africa described complications (other than diarrhoea) and prognosis. ${ }^{33}$ There was an observed $66.7 \%$ mortality rate for patients with CDI and diarrhoea. However, there was no statistical difference in mortality between patients with or without $C$. difficile, nor in length of stay and intensive care admission. Twelve percent of patients with CDI required colectomy, a finding that was significantly associated with the presence of toxigenic $C$. difficile. The presence of toxigenic $C$. difficile has been described in sub-Saharan Africa, but its disease burden and clinical significance, particularly in areas of high HIV prevalence, remain poorly understood.

\section{Conclusions}

There are relatively few studies on CDI in sub-Saharan Africa, but toxigenic $C$. difficile has been detected in the majority of studies designed to look for it in the region, where it has been consistently associated with antibiotic usage. Further in-depth research is needed to define the epidemiology of CDI in sub-Saharan Africa in order to clarify the extent of colonisation within communities and among hospitalised populations, the extent to which CDI is associated with HIV and CD4 count, and its role in contributing to morbidity and mortality.

\section{Acknowledgements}

NJB receives support from the National Institute for Health Research Health Protection Research Unit (NIHR HPRU) in Gastrointestinal Infections at the University of Liverpool in partnership with Public Health England (PHE), University of East Anglia, University of Oxford, and the Institute of Food Research. The views expressed are those of the authors and not necessarily those of the National Health Service (NHS), the NIHR, the Department of Health, or Public Health England. 
Table 1: Published studies on CDI in adults in sub-Saharan Africa, 1995 to present

\begin{tabular}{|c|c|c|c|c|c|c|c|c|c|}
\hline Author & Year & Country & Setting & Controls & $\begin{array}{l}\text { Diagnostic } \\
\text { test for CDI }\end{array}$ & $\begin{array}{l}\text { Sample size } \\
\text { (adults) }\end{array}$ & $\begin{array}{l}\text { CDI } \\
\text { detection } \\
\text { rate (adults) }\end{array}$ & $\begin{array}{l}\text { Antibiotic } \\
\text { association }\end{array}$ & $\begin{array}{l}\text { HIV } \\
\text { association }\end{array}$ \\
\hline Mwachari ${ }^{25}$ & 1998 & Kenya & $\begin{array}{l}\text { HIV positive } \\
\text { adult } \\
\text { inpatients } \\
\text { with chronic } \\
\text { diarrhoea }\end{array}$ & $\mathrm{n} / \mathrm{a}$ & $\begin{array}{l}\text { Cytotoxicity } \\
\text { assay }\end{array}$ & 75 & $0 \%$ & $\mathrm{n} / \mathrm{a}$ & $\mathrm{n} / \mathrm{a}$ \\
\hline Germani $^{28}$ & 1998 & $\begin{array}{l}\text { Central } \\
\text { African } \\
\text { Republic }\end{array}$ & $\begin{array}{l}\text { Adults } \\
\text { presenting to } \\
\text { hospital with } \\
\text { diarrhoea }\end{array}$ & $\begin{array}{l}\text { HIV positive } \\
\text { and negative } \\
\text { non- } \\
\text { diarrhoeal } \\
\text { adult } \\
\text { inpatients }\end{array}$ & $\begin{array}{l}\text { Cytotoxicity } \\
\text { assay }\end{array}$ & 430 & $0.7 \%$ & $\mathrm{n} / \mathrm{a}$ & $\mathrm{n} / \mathrm{a}$ \\
\hline Zulu $^{26}$ & 2000 & Zambia & $\begin{array}{l}\text { HIV positive } \\
\text { adult } \\
\text { inpatients }\end{array}$ & $\mathrm{n} / \mathrm{a}$ & $\begin{array}{l}\text { ELISA for } \\
\text { toxin A }\end{array}$ & 68 & $0 \%$ & $\mathrm{n} / \mathrm{a}$ & $\mathrm{n} / \mathrm{a}$ \\
\hline Samie 29 & 2008 & South Africa & $\begin{array}{l}\text { Adults and } \\
\text { children in } \\
\text { hospital and } \\
\text { community } \\
\text { with } \\
\text { diarrhoea }\end{array}$ & $\begin{array}{l}\text { HIV positive } \\
\text { and negative } \\
\text { non- } \\
\text { diarrhoeal } \\
\text { adult in } \\
\text { hospital and } \\
\text { community }\end{array}$ & $\begin{array}{l}\text { PCR for } \\
\text { cytotoxin } \\
\text { genes }\end{array}$ & 135 & $17.8 \%$ & Yes & No \\
\hline Onwuema ${ }^{27}$ & 2011 & Nigeria & $\begin{array}{l}\text { Adults and } \\
\text { children in } \\
\text { hospital and } \\
\text { community } \\
\text { with } \\
\text { diarrhoea }\end{array}$ & $\begin{array}{l}\text { HIV negative } \\
\text { (or unknown) } \\
\text { adults in the } \\
\text { community }\end{array}$ & $\begin{array}{l}\text { EIA for toxin } \\
A \text { and } B\end{array}$ & 140 & $\begin{array}{l}4.3 \% \\
\text { (community) } \\
\text { to } 43.5 \% \\
\text { (inpatient) }\end{array}$ & $\mathrm{n} / \mathrm{a}$ & Yes \\
\hline Rajabally 30 & 2013 & South Africa & $\begin{array}{l}\text { Adult } \\
\text { inpatients } \\
\text { with } \\
\text { diarrhoea }\end{array}$ & $\mathrm{n} / \mathrm{a}$ & $\begin{array}{l}\text { EIA for toxin } \\
\text { A }\end{array}$ & 643 & $9.2 \%$ & Yes & No \\
\hline Beadsworth ${ }^{31}$ & 2014 & Malawi & $\begin{array}{l}\text { Adult } \\
\text { inpatients } \\
\text { with } \\
\text { diarrhoea }\end{array}$ & $\begin{array}{l}\text { HIV positive } \\
\text { and negative } \\
\text { non- } \\
\text { diarrhoeal } \\
\text { adult } \\
\text { inpatients }\end{array}$ & $\begin{array}{l}\text { ELISA for } \\
\text { toxin A and B }\end{array}$ & 206 & $13.6 \%$ & $\mathrm{n} / \mathrm{a}$ & No \\
\hline Simango $^{32}$ & 2014 & Zimbabwe & $\begin{array}{l}\text { Adults and } \\
\text { children in } \\
\text { community } \\
\text { with } \\
\text { diarrhoea }\end{array}$ & $\mathrm{n} / \mathrm{a}$ & $\begin{array}{l}\text { Culture and } \\
\text { EIA for toxin } \\
\mathrm{A} \text { and B }\end{array}$ & 159 & $6.9 \%$ & $\mathrm{n} / \mathrm{a}$ & $\mathrm{n} / \mathrm{a}$ \\
\hline Kullin ${ }^{33}$ & 2015 & South Africa & $\begin{array}{l}\text { Adults in } \\
\text { hospital and } \\
\text { community } \\
\text { with } \\
\text { diarrhoea }\end{array}$ & $\mathrm{n} / \mathrm{a}$ & $\begin{array}{l}\text { PCR for } \\
\text { cytotoxin } \\
\text { genes }\end{array}$ & 156 & $16 \%$ & $\mathrm{n} / \mathrm{a}$ & $\mathrm{n} / \mathrm{a}$ \\
\hline Seugendo ${ }^{34}$ & 2015 & Tanzania & $\begin{array}{l}\text { Adults and } \\
\text { children } \\
\text { inpatients } \\
\text { with } \\
\text { diarrhoea }\end{array}$ & $\begin{array}{l}\text { Non- } \\
\text { diarrhoeal } \\
\text { adults in } \\
\text { community }\end{array}$ & $\begin{array}{l}\text { Rapid test for } \\
\text { GDH and } \\
\text { PCR for } \\
\text { cytotoxin } \\
\text { genes }\end{array}$ & 33 & $9.1 \%$ & Yes & Yes \\
\hline
\end{tabular}

$\mathrm{CDI}=$ Clostridium difficile infection ELISA = Enzyme-linked immunosorbent assay; $\mathrm{PCR}=$ polymerase chain reaction; EIA = Enzyme immunoassay; $\mathrm{n} / \mathrm{a}=$ not assessed; GDH = glutamate dehydrogenase (Clostridium difficile-specific)

\section{References}

1. Hall IC, O'Toole E. Intestinal flora in new-born infants: with a description of a new pathogenic anaerobe, Bacillus difficilis. Am J Dis Child. 1935;49(2):390-402.

2. Bartlett JG, Chang TW, Gurwith M, Gorbach SL, Onderdonk AB. Antibiotic-associated pseudomembranous colitis due to toxinproducing clostridia. N Engl J Med. 1978 Mar 9;298(10):531—4.

3. Leffler DA, Lamont JT. Clostridium difficile infection. N Engl J Med. 2015;372(16):1539-48.
4. Vedantam G, Clark A, Chu M, McQuade R, Mallozzi M, Viswanathan VK. Clostridium difficile infection: toxins and non-toxin virulence factors, and their contributions to disease establishment and host response. Gut Microbes. 2012;3(2):121-34.

5. Rupnik M. Is Clostridium difficile-associated infection a potentially zoonotic and foodborne disease? Clin Microbiol Infect. 2007 May;13(5):457-9.

6. Otter JA, Yezli S, French GL. The role played by contaminated surfaces in the transmission of nosocomial pathogens. Infect Control Hosp Epidemiol. 2011 Jul;32(7):687-99. 
7. Davies AH, Roberts AK, Shone CC, Acharya KR. Super toxins from a super bug: structure and function of Clostridium difficile toxins. Biochem J. 2011;436(3):517-26.

8. Warny M, Pepin J, Fang A, Killgore G, Thompson A, Brazier J, et al. Toxin production by an emerging strain of Clostridium difficile associated with outbreaks of severe disease in North America and Europe. Lancet. 2005 Sep 24-30;366(9491):1079-84.

9. Kachrimanidou M, Malisiovas N. Clostridium difficile infection: a comprehensive review. Crit Rev Microbiol. 2011 Aug;37(3):178-87.

10. Jones AM, Kuijper EJ, Wilcox MH. Clostridium difficile: a European perspective. J Infect. 2013 Feb;66(2):115-28.

11. He M, Miyajima F, Roberts P, Ellison L, Pickard DJ, Martin MJ, et al. Emergence and global spread of epidemic healthcare-associated Clostridium difficile. Nat Genet. 2013;45(1):109-13.

12. Bartlett JG, Gerding DN. Clinical recognition and diagnosis of Clostridium difficile infection. Clin Infect Dis. 2008 Jan 15;46(Supplement 1):S12-S18.

13. Bartlett JG. Historical perspectives on studies of Clostridium difficile and C. difficile infection. Clin Infect Dis. 2008 Jan 15;46(Supplement 1):S4-S11.

14. Leffler DA, Lamont JT. Treatment of Clostridium difficileassociated disease. Gastroenterology. 2009 May;136(6):1899-1912.

15. Chitnis AS, Holzbauer SM, Belflower RM, Winston LG, Bamberg WM, Lyons C, et al. Epidemiology of community-associated Clostridium difficile infection, 2009 through 2011. JAMA Intern Med. 2013 Jul 22;173(14):1359-67.

16. Dial S, Delaney JA, Barkun AN, Suissa S. Use of gastric acidsuppressive agents and the risk of community-acquired Clostridium difficile-associated disease. JAMA. 2005 Dec 21;294(23):2989-95.

17. Novack L, Kogan S, Gimpelevich L, Howell M, Borer A, Kelly CP, et al. Acid suppression therapy does not predispose to Clostridium difficile infection: the case of the potential bias. PLoS One. 2014;9(10):e110790.

18. Bartlett JG. Changing trends in bacterial infections: Staphylococcus aureus, bacterial pneumonia, Clostridium difficile. Top HIV Med. 2007 Jun-Jul;15(3):94-8.

19. Sanchez TH, Brooks JT, Sullivan PS, Juhasz M, Mintz E, Dworkin MS, et al. Bacterial diarrhea in persons with HIV infection, United States, 1992-2002. Clin Infect Dis. 2005 Dec 1;41(11):1621-7.

20. Collini PJ, Bauer M, Kuijper E, Dockrell DH. Clostridium difficile infection in HIV-seropositive individuals and transplant recipients. J Infect. 2012 Feb;64(2):131-47.

21. Haines CF, Moore RD, Bartlett JG, Sears CL, Cosgrove SE, Carroll $\mathrm{K}$, et al. Clostridium difficile in a HIV-infected cohort: incidence, risk factors, and clinical outcomes. AIDS. 2013 Nov 13;27(17):2799-807.

22. Torre D. Is Clostridium difficile the leading pathogen in bacterial diarrhea in HIV type 1-infected patients? Clin Infect Dis. $2006 \mathrm{Apr}$ 15;42(8):1215-16; author reply 1216 .

23. Allegranzi B, Bagheri Nejad S, Combescure C, Graafmans W, Attar H, Donaldson L, et al. Burden of endemic health-care-associated infection in developing countries: systematic review and meta-analysis. Lancet. 2011 Jan 21;377(9761):228-41.

24. Becker J, Drucker E, Enyong P, Marx P. Availability of injectable antibiotics in a town market in southwest Cameroon. Lancet Infect Dis. 2002 Jun;2(6):325-6.

25. Mwachari C, Batchelor BIF, Paul J, Waiyaki PG, Gilks CF. Chronic diarrhoea among HIV-infected adult patients in Nairobi, Kenya. J Infect. 1998;37(1):48-53.

26. Zulu I, Kelly P, Mwansa J, Veitch A, Farthing MJ. Contrasting incidence of Clostridium difficile and other enteropathogens in AIDS patients in London and Lusaka. Trans R Soc Trop Med Hyg. 2000 MarApr;94(2):167-8.
27. Onwueme K, Fadairo Y, Idoko L, Onuh J, Alao O, Agaba P, et al. High prevalence of toxinogenic Clostridium difficile in Nigerian adult HIV patients. Trans R Soc Trop Med Hyg. 2011;105(11):667-9.

28. Germani Y, Minssart P, Vohito M, Yassibanda S, Glaziou P, Hocquet D, et al. Etiologies of acute, persistent, and dysenteric diarrheas in adults in Bangui, Central African Republic, in relation to human immunodeficiency virus serostatus. Am J Trop Med Hyg. 1998 Dec;59(6):1008-14.

29. Samie A, Obi CL, Franasiak J, Archbald-Pannone L, Bessong PO, Alcantara-Warren $\mathrm{C}$, et al. PCR detection of Clostridium difficile triose phosphate isomerase (tpi), toxin A (tcdA), toxin B (tcdB), binary toxin (cdtA, cdtB), and tcdC genes in Vhembe District, South Africa. Am J Trop Med Hyg. 2008 Apr;78(4):577-85.

30. Rajabally NM, Pentecost M, Pretorius G, Whitelaw A, Mendelson M, Watermeyer G. The Clostridium difficile problem: a South African tertiary institution's prospective perspective. S Afr Med J. 2013 Mar;103(3):168-72.

31. Beadsworth MBJ, Keeley AJ, Roberts P, Watson A, Beeching NJ. Clostridium difficile toxin in adult inpatients in an urban hospital in Malawi: associations with HIV status, CD4 count and diarrhoea. Int J Trop Med. 2014;9(1):7-9.

32. Simango C, Uladi S. Detection of Clostridium difficile diarrhoea in Harare, Zimbabwe. Trans R Soc Trop Med Hyg. 2014 Jun;108(6):3547.

33. Kullin B, Meggersee R, D'Alton J, Galvao B, Rajabally N, Whitelaw A, et al. Prevalence of gastrointestinal pathogenic bacteria in patients with diarrhoea attending Groote Schuur Hospital, Cape Town, South Africa. S Afr Med J. 2015 Feb;105(2):121—5.

34. Seugendo M, Mshana SE, Hokororo A, Okamo B, Mirambo MM, von Müller L, et al. Clostridium difficile infections among adults and children in Mwanza/Tanzania: is it an underappreciated pathogen among immunocompromised patients in sub-Saharan Africa? New Microbes New Infect. 2015 Nov 22;8:99-102.

35. Planche T, Wilcox M, Walker AS. Fecal-free toxin detection remains the best way to detect Clostridium difficile infection. Clin Infect Dis. 2015 Oct 1;61(7):1210-1.

36. Rao K, Micic D, Natarajan M, Winters S, Kiel MJ, Walk ST, et al. Clostridium difficile ribotype 027: relationship to age, detectability of toxins A or B in stool with rapid testing, severe infection, and mortality. Clin Infect Dis. 2015 Jul 15;61(2):233-41.

37. Longtin Y, Trottier S, Brochu G, Paquet-Bolduc B, Garenc C, Loungnarath $\mathrm{V}$, et al. Impact of the type of diagnostic assay on Clostridium difficile infection and complication rates in a mandatory reporting program. Clin Infect Dis. 2013 Jan;56(1):67-73.

38. Polage CR, Gyorke CE, Kennedy MA, Leslie JL, Chin DL, Wang S, et al. Overdiagnosis of Clostridium difficile infection in the molecular test era. JAMA Intern Med. 2015 Nov 1;175(11):1792-1801.

39. Ozaki E, Kato H, Kita H, Karasawa T, Maegawa T, Koino Y, et al. Clostridium difficile colonization in healthy adults: transient colonization and correlation with enterococcal colonization. J Med Microbiol. 2004 Feb;53(Pt 2):167-72.

40. Riggs MM, Sethi AK, Zabarsky TF, Eckstein EC, Jump RLP, Donskey CJ. Asymptomatic carriers are a potential source for transmission of epidemic and nonepidemic Clostridium difficile strains among long-term care facility residents. Clin Infect Dis. 2007 Oct 15;45(8):992-8. 